\title{
Pengaruh Peran Kegiatan Pukung Pahewan Masyarakat Suku Dayak terhadap Rona Lingkungan Alam Kalimantan
}

\author{
Muh. Azhari \\ Program Studi Teknik Lingkungan Universitas Muhammadiyah Palangkaraya \\ email: arymuh@gmail.com
}

\begin{abstract}
ABSTRAK. Kearifan kehidupan manusia merupakan salah satu faktor yang mempengaruhi kondisi keberlanjutan lingkungan ke arah lebih baik. Sehingga peranan dari manusia baik perorangan dan kelompok tidak dapat dipisahkan dari kondisi lingkungan saat ini. Misalnya seperti kebiasaan yang dimiliki oleh masyarakat Suku Dayak dan berpengaruh terhadap kondisi lingkungan diantaranya kegiatan Pukung Pahewan. Kegiatan Pukung Pahewan merupakan kegiatan masyarakat yang mengkramatkan hutan, sehingga hutan tidak boleh diganggu. Metode penelitian yang digunakan dalam penelitian ini merupakan metode etnografi. Teknik pengumpulan data yang digunakan diantaranya seperti wawancara dan studi dokumentasi terkait dengan kegiatan yang diteliti.
\end{abstract}

Kata kunci : pukung pahewan, suku dayak, lingkungan

\section{PENDAHULUAN}

Laporan beberapa lembaga pemerhati lingkungan menuturkan bahwa luas hutan yang hilang perharinya seluas dua kali lapangan sepak bola. Ukuran lapangan sepak bola yaitu 100 sampai dengan 110 meter dengan lebar 64 meter sampai dengan 74 meter standar internasional. Sedangkan luas hutan yang hilang setiap tahunnya dari aktifitas manusia seperti penebangan liar, alih fungsi, pembukaan hutan tanpa ada solusi pengganti yaitu seluas 2 sampai dengan 2,5 juta hektar. Padahal hutan adalah paru-paru dunia. Hanya hutan yang di dalamnya ada pohon yang mampu merombak gak buang dari hewan dan manusia seperti gas karbondioksida.

Gas karbondioksida merupakan salah satu jenis gas rumah kaca (GRK), jika tidak seimbang antara produsen gas tersebut (hewan dan manusia) dengan pengurai/perombak (Tumbuhan) maka akan timbul permasalahan baru yang merugikan bagi manusia. Kerugian tersebut tidak dapat dibayar dengan material dimiliki, karena hal tersebut merupakan sebuah nilai yang tidak dapat di ukur dengan material uang.

Pengukuran dengan material aliran pemikiran materialisme yang memandang semuanya dapat di beli dengan uang akan menyebabkan laju kerusakan lingkungan akan semakin cepat. Sehingga suatu saat manusia akan mengeluh akan masalah yang timbul di lingkungan tempat tinggal mereka. Maka saat itu mereka akan berfikir bahwa air, tanah, udara yang baik jauh lebih berharga dibandingkan material yang mereka miliki. Karena perlu diketahui, ketika kualitas lingkungan hidup menurun, maka kualitas kehidupan manusia akan berbanding lurus, yaitu kualitasnya menurun. Bahkan akan menimbulkan banyak permasalahan, misalnya di bidang kesehatan dan penyakit.

Kesehatan dan penyakit yang diakibatkan oleh lingkungan yang kualitasnya buruk akibat aktivitas manusia dalam 
pemenuhan kebutuhan hidupnya harus ditanggung manusia. Ada harga yang harus dibayar dari model hidup yang dilakukan manusia. Oksigen yang berbayar dan air yang berbayar. Hal tersebut terjadi karena sumberdaya yang langka, sumberdaya yang melimpah akan tetapi tidak dapat digunakan secara optimal karena risiko yang dikandung diantaranya mengandung bahan pencemar.

Kesehatan yang terganggu akibat lingkungan yang terganggu diantaranya seperti ISPA, Gangguan saluran cerna, strees, mutasi genetik, paparan radioaktif. Tentu kesehatan adalah harga yang mahal untuk sebuah kegiatan pengrusakan tanpa ada solusi yang ditawarkan. Sehingga perlu langkah yang tepat untuk mengurangi permasalahan tersebut, salah satunya adalah dengan meningkatkan kualitas sumberdaya manusia dan mempertahankan warisan budaya atau kearifan lokal oleh para leluhur, misalnya seperti kearifan lokal yang dimiliki oleh masyarakat Suku Dayak. Kegiatan tersebut seperti Pukung Pahewan.

\section{METODE PENELITIAN}

Pendekatan penelitian yang digunakan dalam penelitian ini dilakukan secara etnografi. Kajian warisan budaya yang miliki oleh masyarakat Suku Dayak dan berpengaruh terhadap kondisi lingkungan, baik lahan, hutan maupun kebun (Nila Riwut. 2015).

Kondisi kehidupan masyarakat dan warisan budaya yang ada sangat mempengaruhi persepsi dan penciptaan makna pada setiap peristiwa sosial, yang dalam kehidupan sosial selalu melibatkan hubungan intersubyektif dan pembentukan makna (Sutopo, 2006). Teknik pengumpulan data dalam penelitian ini dilakukan dengan cara wawancara dan kajian dokumentasi terkait dengan kearifan budaya lokal Masyarakat Suku Dayak dalam memperlakukan lingkungan seperti memperlakukan diri sendiri atau teman hidup.

\section{HASIL DAN PEMBAHASAN}

Masyarakat Suku Dayak merupakan masyarakat yang dominan tinggal di Pulau Kalimantan. Warisan budaya yang dimiliki sangat beraneka ragam. Budaya tersebut dapat menjamin keberlanjutan keberlangsungan lingkungan dengan baik. Misalnya seperti kegiatan Pukung Pahewan.

Warisan kegiatan budaya Pukung Pahewan merupak kearifan lokal yang harus dipertahankan karena dianggap mampu menahan laju deforestasi dan pengrusakan lingkungan yang tidak bertanggung jawab. Pukung pahewan merupakan kegiatan kearifan lokal Suku Dayak untuk menjaga hutan dengan cara dikeramatkan dan dijaga oleh makhluk halus. Sehingga hutan tersebut tidak diganggu. Hal ini dapat berfungsi sebagai bentuk pelestarian lingkungan.

Akan tetapi permasalahan lainnya adalah adanya gerusan dari kehidupan modernisasi yang menyebabkan terkikisnya tersingkirnya budaya di masyarakat, sehingga peranan dari pemerintah dan masyarakat sangat penting agar budaya yang dimiliki oleh masyarakat Suku Dayak tidak hilang dan tetap menjadi warisan budaya yang tidak ternilai harganya.

Manusia dengan lingkungan merupakan dua hal yang tidak dapat dipisahkan. Karena terikat satu sama lain, terhubung dan memberikan pengaruh terhadap keberlanjutan kedua hal tersebut. Akan tetapi jika manusia salah memperlakukan lingkungan, maka halhal yang tidak diinginkan dan tidak dapat diprediksi dapat menjadi masalah baru bagi manusia. Lingkungan merupakan kesatuan ruang dengan semua benda, daya keadaan dan makhluk hidup, singkatnya antara komponen biotik dan komponen abiotik (UU No. 32 Tahun 2009).

Antropocentrisme, Ecocentrisme, Feminisme dan lainnya merupakan hasil pemikiran manusia terhadap kondisi dan perilaku manusia terhadap alam lingkungan (Nurdiana. 2016). Manusia yang melakukan, manusia juga yang akan menuai. Jadi manusia harus bijak dalam pengelolaan dan perlindungan lingkungan. Seperti yang diamanatkan dalam UU No. 32 tahun 2009 tentang Perlindungan dan Pengelolaan Lingkungan Hidup.

Perlindungan dan pengelolaan lingkungan hidup merupakan upaya sistematis 
dan terpadu yang dilakukan untuk melestariak fungsi lingkungan hidup dan mencegah terjadinya pencemaran dan/atau kerusakan lingkungan hidup yang meliputi perencanaa, pemanfaatan, pengendalian, pemeliharaan, pengawasan, dan penegakan hukum. (UU No. 32 Tahun 2009). Misalnya salah satunya dengan menciptakan interaksi dan simbiosis yang sama-sama menguntungkan sehingga anak cucu atau generasi yang akan datang juga dapat merasakan alam yang kita rasakan saat ini, jangan hanya diwariskan cerita-cerita tanpa ada material nyata untuk mereka. Misalnya mengenai kekayaan dan keindahan alam lingkungan di sekitar mereka. Pelestarian lingkungan tersebut dapat dilakukan dengan salah satu cara mewariskan budaya yang arif terhadap lingkungan misalnya budaya masyarakat Suku Dayak yang terbentuk dari liar (alami) lingkunganhidup mereka (Nila Riwut. 2014).

Lingkungan membentuk karakteristik masyarakat yang tinggal di lingkungan tersebut karena adanya interaksi yang terbentuk. Karakteristik manusia tersebut seiring dengan pendapat paradigma Human Exceptionalism Paradigm (HEP) yang mengatakan bahwa manusia bersifat unik dan berbeda dengan makhluk lainnya karena mendapatkan warisan budaya (Rachmad. 2012).

Pemikiran lainnya dari paradigma New Ecologial Paradigm menjelaskan bahwa manusia memiliki perkecualian, tetapi tetap merupakan satu di antara banyak spesies yang saling bergantung pada ekosistem/lingkungan. Hal ini mengharuskan manusia memperhatikan lingkungannya supaya tetap ada dan kualitasnya terjaga. Misalnya seperti yang dilakukan masyarakat Suku Dayak terhadap lingkungan dalam kegiatan Pukung Pahewan.

Masyarakat Suku Dayak merupakan masyarakat merupakan masyarakat yang tinggal di Pulau Kalimantan dengan persebarannya. Suku Dayak secara garis besar diantaranya seperti Suku Dayak Ngaju, Suku Dayak Apu Kayan, Suku Dayak Iban, Heban atau Dayak Laut, Suku Dayak Murut, Suku Dayak Punan dan Suku Dayak Ot Danum (Nila Riwut. 2015).
Sifat masyarakat Suku Dayak memiliki jiwa ksatria, pemberani, pantang menyerah. Hal ini terungkap dalam semboyan hidup mereka yaitu Isen Mulang yang berarti pantang menyerah. Perkembangan lainnya masyarakat Suku Dayak melalui proses kehidupan, mengamati, menghayati, memahami lingkungan dan ganasnya alam, bahwa mereka tidak mampu menaklukkan alam tetapi mereka dapat bersahabat dengan alam. Mengganggap alam adalah ibu bagi mereka, apa yang mereka minta pada alam akan dikasih. Sehingga alam harus dijaga dengan baik. Seperti dengan cara mengkramatkan alam, sehingga laju keruskan alam dapat di kontrol.

\section{KESIMPULAN}

Manusia dengan alam lingkungan tidak dapat dipisahkan. Sehingga perlu cara yang tepat untuk menjaga alam lingkungan supaya tetap lestari, misalnya dengan menjaga warisan budaya kearifan lokal yang ada. Misalnya yang dimiliki oleh masyarakat Suku Dayak seperti Pukung Pahewan. Pukung Pahewan merupakan kegiatan mensakralkan alam seperti hutan. Bahwa hutan tersebut dijaga oleh makhluk halus sehingga masyarakat tidak berani merusak hutan tersebut.

\section{SARAN}

Warisan budaya yang arif dan bijaksana seperti yang dimiliki Masyarakat Suku Dayak harus dijaga dan dilestarikan karena berpengaruh terhadap kondisi alam lingkungan. Laju modernisasi dan kebutuhan manusia yang semakin meningkat serta perkembangan Ilmu Pengetahuan dan Teknologi menyebabkan budaya yang ada tergerus oleh zaman, faktor lainnya yang mempengaruhi diantaranya seperti ketika masyarakat Suku Dayak mengenal agama baru. Sehingga ritual-ritual budaya yang dimiliki banyak ditinggalkan atau tidak dilakukan lagi. Jadi peranan masyarakat dan pemerintah sangat penting untuk mempertahankan warisan budaya yang sudah ada. 


\section{DAFTAR PUSTAKA}

Nila. R., 2015, Maneser Panatau Tatu Hiang. NR Publishing, Yogyakarta.

, 2014, Bawin Dayak, NR Publishing, Yogyakarta

Nurdiana, 2016, Ilmu Alamiah Dasar, Pustaka Lombok, Lombok NTB

Rachmad, K., 2012, Sosiologi Lingkungan, PT. Rajagrafindo Persada, Jakarta.

UU No. 32 Tahun 2009 Tentang Perlindungan dan Pengelolaan Lingkungan Hidup. Kementerian Lingkungan Hidup. Jakarta. 